Jahangirnagar University J. Biol. Sci. 6(1): 13-22, 2017 (June)

\title{
Occupational health hazards and safety practices among the workers of tannery industry in Bangladesh
}

\author{
Rabiul Islam, Md. Shakhaoat Hossain" and Md. Abu Bakkar Siddique ${ }^{1}$ \\ Department of Public Health and Informatics, Jahangirnagar University, Savar, \\ Dhaka-1342, Bangladesh
}

\begin{abstract}
In Bangladesh, workers of the tannery industries are commonly affected with several health hazards. The aim of this study was to determine the prevalence and patterns of health problems of the tannery workers, and to find out the factors associated with those health problems. A cross sectional studywas conducted on 316 general tannery workers (who work with raw hides and chemicals only) from 22 different tanneries in Hazaribagh, Dhaka, Bangladesh. A standardized, structured face to face interviewer-administered close ended questionnaire was used for data collection. Data were analyzed using descriptive statistics, logistic regression models and chi-square test. Around $63.3 \%$ of workers were affected with at least one health problems. Majority of the workers were suffering from skin problem $(25.3 \%)$, gastrointestinal problem $(8.5 \%)$, chronic headache $(8.2 \%)$, allergies $(5.7 \%)$, respiratory system problem $(6.3 \%)$, cardiovascular problem $(6.3 \%)$ and eye problem (3.5\%). Only $36.7 \%$ respondents used personal protective equipment (PPE). The tanneries did not have any effluents or wastes treatment facilities. Smoking and monthly low household income were significantly associated with the morbidity of the tannery workers. The government should take adequate measures to mitigate the health hazards in the tannery industry.
\end{abstract}

Key words: Health hazard, safety practices, tannery workers, Bangladesh.

\section{INTRODUCTION}

Tanning industry in Bangladesh is one of the oldest manufacturing sub-sectors for over six decades and this sector contributes 3-4\% growth of the total economy of the country (GTZ, 2010; Azom et al., 2012). Among 313 leather and manufacturing units in Bangladesh, approximately 300 of the tanneries are situated in Hazaribagh, Dhaka (Billah, 2000). In developed countries, the production of leather has been tremendously reduced due to the closure of tanneries brought about by strict environmental laws. Developing countries have inadequate environmental protection measures due to limited relevant policies and lack of enforcement of existing legislation (Febrina et al., 2012; Were et al., 2013). The third world countries, especially Bangladesh is now in a vulnerable position regarding the industrial pollution issues (Nuruzzaman et al., 1992). It has been reported that these tanneries are responsible for serious environmental threats by discharging untreated liquid effluents and solid wastes directly into the surrounding low lying areas which contains high amount of heavy metals such as $\mathrm{Cr}, \mathrm{Cu}, \mathrm{As}, \mathrm{Cd}, \mathrm{Fe}, \mathrm{Hg}$, $\mathrm{Mn}, \mathrm{Ni}, \mathrm{Pb}$ and $\mathrm{Zn}$ (Larson et al., 1975; Huq, 1998; Human Rights Watch, 2012). Previous studies reported that residents near the Hazaribagh tannery had higher morbidity

\footnotetext{
${ }^{1}$ International Centre for Diarrhoeal Disease Research, Bangladesh (icddr,b), Dhaka 1000, Bangladesh

*Corresponding author. E-mail: shakhaoat@juniv.edu
} 
compared to people living 2 to $3 \mathrm{~km}$ apart (Huq, 1998; Chowdhury, 2011; Human Rights Watch, 2012). Therefore, it is important to know the level of health of the tannery workers and take remedial action. This study was designed to determine the tannery induced disease prevalence and patterns among the tannery workers and to identify the health hazards of the tannery workers. It was also decided to measure the knowledge, attitude and practice of the personal protective equipments use among the tannery workers and finally to explore the health seeking behaviors of the tannery workers in Bangladesh.

\section{MATERIALS AND METHODS}

Study area and population: The study was conducted at Hazaribagh area under Hazaribagh Thana in Dhaka City Corporation where approximately 300 tanneries are located. Voluntary participation of full time tannery workers with all ages (both male and female), who worked with raw hides and chemicals, were only included in the study.

Study design and sampling: A cross sectional study was conducted among 316 tannery workers of 22 different tannery industries following quantitative data collection methods. The tanneries were selected purposively and the workers were selected randomly. Before data collection, pilot study among 46 tannery workers were conducted. From pilot study, the disease prevalence rate was $72 \%$, keeping $95 \%$ confidence interval (CI) and absolute precision required 0.05 , minimum sample size came out 310 .

Data collection: A standardized structured close-ended questionnaire was used for data collection. The questionnaire was prepared in English and asked directly by translating into Bangla. A trained data collection team consisting of 12 members collected data using face to face interviews. Permissions from every tannery industry authority and verbal consent from the tannery workers were taken in advance. Respondents had complete liberty not to response to any of the questions and leave the interview at any time during the study. The interviewer-administered questionnaire included socio-demographic (age, sex, education, marital status, and family background, including saving status, water source and income levels), working information knowledge and personal protective equipment's use (working hour, duration of job, training status, knowledge regarding chemicals and hand washing practice), working environment characteristics (ventilation, lighting, temperature, noise, smell, waste management facilities of the tannery and smoking status), health problems and treatment status of the tannery workers.

Data analysis: Data were analyzed by using SPSS (Statistical Package for Social Science, version 20) software and Microsoft excel (version 2010). Descriptive statistics for categorical variables frequencies and proportions; means and standard deviations for continuous were calculated. Logistic regression and chi-square test were used to explore significant association between health problems and others variables (age, sex, education, income, duration of job in year, working hours, protective equipment use, smoking status of the tannery workers, marital status, knowledge about chemicals and working environments). Odds ratio (OR), 95\% CI and p-value (significant at $P<0.05$ ) were used for interpretation. 


\section{RESULTS AND DISCUSSION}

Socio-demographic characteristics of the respondents are presented in Table 1. Among 316 respondents, 290 were male and 26 were female. The data showed that majority (46.5\%) of the tannery workers were young adult aged between 21 years and 30 years.

Table 1. Socio-demographic characteristics of the tannery workers, Hazaribagh, Bangladesh

\begin{tabular}{lcc}
\hline Background characteristics & $\begin{array}{c}\text { Percentage } \\
(\%)\end{array}$ & $\begin{array}{c}\text { Number of tannery } \\
\text { workers (N=316) }\end{array}$ \\
\hline Sex $\quad$ & \\
$\quad$ Male & 92.0 & 290 \\
$\quad$ Female & 8.0 & 26 \\
Age (year) & 5.4 & 17 \\
$<20$ & 46.5 & 147 \\
$21-30$ & 32.9 & 104 \\
$31-40$ & 15.2 & 48 \\
$41+$ & & \\
Education & 37.3 & 118 \\
$\quad$ No education & 28.2 & 89 \\
Primary incomplete & 16.8 & 53 \\
$\quad$ Primary complete & 13.6 & 43 \\
Secondary incomplete & 4.1 & 13 \\
Secondary complete or higher & & \\
Monthly income (taka)of the tannery workers & 10.1 & 32 \\
$\quad$ Less than 8000 & 53.8 & 170 \\
8000-10000 & 27.5 & 87 \\
10000-12000 & 8.5 & 27 \\
$\quad$ More than 12000 & & \\
Duration of job (year) & & 172 \\
$\quad 5$ & 54.4 & 99 \\
6-10 & 31.3 & 45 \\
10+ & 14.2 & 8 \\
Daily working hours & & 256 \\
6-7 & 2.5 & 52 \\
8-9 & 81.0 & 171 \\
10+ & 16.5 & 145 \\
Smoking status of the tannery workers & & \\
$\quad$ Smoke & 54.0 & \\
Do not smoke & 46.0 & \\
\hline
\end{tabular}

The study showed that maximum workers were illiterate, $37.3 \%$ workers were with little education at all. The study demonstrated that job duration of $54.4 \%$ tannery workers was less than 5 years, $31.3 \%$ was 6 years to 10 years and $14.2 \%$ was above 10 years. Most of the tannery workers (54\%) smoked and all of them were male moreover, all of them smoked inside the workplace that is responsible for passive smoking for other workers thus the unhealthy tannery environment and smoking practice is the big concern for tannery workers. 
The results revealed that the tannery workers enters into their works without prior training though $73.7 \%$ of them agreed that they require training before entering into the job. (Table 2) In this study, $84.2 \%$ respondents believed that the chemicals used in the tannery are harmful for health and $64.1 \%$ the respondents knew that these chemicals can cause cancers. The results showed that $90.5 \%$ the respondents know that protective equipment's can reduce the exposure of the chemicals. Among 316 tannery workers 116 (36.7\%) used personal protective equipment's and 200 (63.3\%) workers did not use personal protective equipment's. This study also showed that the workers were working in the unhealthy environment for long time without using protective equipment's which might cause many health problems to the tannery workers.

Table 2. Training status, Knowledge and use of Personal Protective Equipment's by the tannery workers, Hazaribagh, Bangladesh

\begin{tabular}{|c|c|c|}
\hline Training status, Knowledge and PPE use & $\begin{array}{l}\text { Percentage } \\
\quad(\%)\end{array}$ & $\begin{array}{l}\text { Number of tannery } \\
\text { workers }(\mathrm{N}=316)\end{array}$ \\
\hline \multicolumn{3}{|c|}{ Formal training status before working with tannery machines and chemicals* } \\
\hline With training & 0.0 & 0 \\
\hline Without training* & 100 & 314 \\
\hline \multicolumn{3}{|c|}{ Do the workers believe before entering into job the workers require training? } \\
\hline Yes & 73.7 & 233 \\
\hline No & 26.3 & 83 \\
\hline \multicolumn{3}{|c|}{ Do the workers know chemicals used in the tannery are harmful for health? } \\
\hline Yes & 84.2 & 266 \\
\hline No & 15.8 & 50 \\
\hline \multicolumn{3}{|c|}{ Do the workers think chemicals used in the tannery can cause cancer? $* *$} \\
\hline Yes & 64.1 & 202 \\
\hline No & 35.9 & 113 \\
\hline \multicolumn{3}{|c|}{$\begin{array}{l}\text { Do the workers know personal Protective equipment's can reduce the exposure of the } \\
\text { chemicals? }\end{array}$} \\
\hline Yes & 90.5 & 286 \\
\hline No & 9.5 & 30 \\
\hline \multicolumn{3}{|l|}{ Do the workers use protective equipment's? } \\
\hline Yes & 36.7 & 116 \\
\hline No & 63.3 & 200 \\
\hline $\begin{array}{l}\text { Source of protective equipment's used } \\
\text { by the workers }\end{array}$ & & $(\mathrm{n}=116)$ \\
\hline Self & 49.0 & 57 \\
\hline Tannery & 60.0 & 59 \\
\hline
\end{tabular}

*There was two case missing

**There was one case missing

Tannery workers suffer from many health problems, among them Skin problem, Gastrointestinal problem, Chronic head ache, Respiratory system problem (Asthma, COPD, chronic bronchitis), Cardiovascular problem (Hypertension/stroke/heart disease) are more common. Table 3 shows the prevalence and patterns of various health problems of the tannery workers due to tannery activities. Among 316 workers, 200 (63.3\%) were suffering from health problems. During the present study, it was recorded that $25.3 \%$ of the tannery workers were suffering from Skin Disorder. 
Table 3. Prevalence and patterns of health problems of the tannery workers, Hazaribagh, Bangladesh

\begin{tabular}{|c|c|c|c|}
\hline Health problems of the tannery workers & $\begin{array}{l}\text { Percentage } \\
\quad(\%)\end{array}$ & $\begin{array}{c}\text { Number of } \\
\text { tannery } \\
\text { workers } \\
(\mathrm{N}=316) \\
\end{array}$ & $\begin{array}{l}\text { Average suffering } \\
\text { from disease (in } \\
\text { months) with(SD) }\end{array}$ \\
\hline \multicolumn{4}{|l|}{ Suffering from health problems } \\
\hline Yes & 63.3 & 200 & \\
\hline No & 36.7 & 116 & \\
\hline \multicolumn{4}{|c|}{ Disease specific sufferings of the tannery workers out of 316} \\
\hline Skin problem & 25.3 & 80 & $50.5(41.1)$ \\
\hline Gastrointestinal problem & 8.5 & 27 & $39.1(23.4)$ \\
\hline Chronic head ache & 8.2 & 26 & 25.3(14.8) \\
\hline Sterility/ loss of libido & 0.9 & 3 & $48.0(12.0)$ \\
\hline Eye problem & 3.5 & 11 & $37.0(32.8)$ \\
\hline Allergies & 5.7 & 18 & $74.0(39.1)$ \\
\hline Diarrhea & 4.1 & 13 & $29.3(29.6)$ \\
\hline Leprosy & 1.9 & 6 & $42.0(14.6)$ \\
\hline Tuberculosis & 1.3 & 4 & $63.0(26.6)$ \\
\hline $\begin{array}{l}\text { Respiratory system problem (Asthma, } \\
\text { COPD, chronic bronchitis) }\end{array}$ & 6.3 & 20 & $45.6(37.4)$ \\
\hline Jaundice & 1.6 & 5 & $34.8(30.7)$ \\
\hline Fever & 2.5 & 8 & $13.8(11.1)$ \\
\hline Low birth weight or immature babies & 0.6 & 2 & $24.0(16.9)$ \\
\hline Abortion & 0.6 & 2 & $42.0(8.48)$ \\
\hline Hearing problem & 2.2 & 7 & $49.7(28.1)$ \\
\hline $\begin{array}{l}\text { Cardiovascular problem } \\
\text { (Hypertension/stroke/heart disease) }\end{array}$ & 6.3 & 20 & $50.0(27.4)$ \\
\hline Musculo-skeletal problem & 3.2 & 10 & $45.6(37.4)$ \\
\hline Neurological disorders & 0.6 & 2 & $46.5(53.03)$ \\
\hline $\begin{array}{l}\text { Mental health problem (psychological } \\
\text { problem/depression/anxiety) }\end{array}$ & 0.9 & 3 & $116.0(55.42)$ \\
\hline Renal problem (Urinary tract problems) & 1.3 & 4 & $27.0(11.4)$ \\
\hline Trauma/ injury & 3.2 & 10 & $17.0(14.4)$ \\
\hline Loss of appetite & 2.5 & 8 & $24.2(15.0)$ \\
\hline Sleep disturbance & 0.6 & 2 & $30.0(8.4)$ \\
\hline Nail problem & 0.6 & 2 & $24.0(0.0)$ \\
\hline Loss of smell (Anosmia) & 3.2 & 10 & $48.0(76.73)$ \\
\hline
\end{tabular}

* SD-Standard Deviation

This study indicates that $8.5 \%$ of the respondents were suffering from Gastrointestinal problem whereas in the previous study of Yogaraj et al. (2014) it was 2.6\% and 13.9\% was stated by the study of Arjunan (2015). On the other hand, $8.2 \%$ of the respondents had been found to be suffering from chronic headache whereas Arjunan (2015) found $47.9 \%$ that was higher than the present study. The study reported that $9 \%$ of the respondents were suffered from Sterility/ loss of libido that was higher than the findings of the study of Arjunan (2015) which was 6.8\%. Rastogi et al. (2008) reported that $14.7 \%$ of the tannery workers were suffering from eye problem whereas this study found that 
only $3.5 \%$ of the responded were in eye problems. Arjunan (2015) reported that $7.1 \%$ of the tannery workers were suffered from allergy whereas in this study $5.7 \%$ of the respondents were suffering from allergy. Previously Gangopadhyay et al. (2011) found that $16.7 \%$ of the tannery workers suffered from respiratory system problem (Asthma, COPD, chronic bronchitis) but in this study found that only $6.3 \%$ of the workers were suffering from this health problem. The tannery workers did not get proper training before entering into the job. The workers were handling the machines and drams improperly that caused trauma/ injury (mainly hand and leg injury).

Environmental condition of the working place in the tannery industry is very important for maintaining good health of the tannery workers. Table 4 demonstrates the environmental conditions of the workplace in the tannery industry. Among 22 tanneries, 20 were poorly ventilated and 200 workers were suffering from different diseases, 183 (91.5\%) workers were working in this poor ventilated environment. These unhealthy activities of the tanneries were responsible for environmental pollution and health problems of the tannery workers and residents in Hazaribagh area.

Table 4. Environmental condition of the workplace in the tannery industry Hazaribagh, Bangladesh

\begin{tabular}{|c|c|c|c|c|c|c|c|c|}
\hline \multicolumn{2}{|c|}{$\begin{array}{l}\text { Environmental condition } \\
\text { in the tannery industry }\end{array}$} & $\begin{array}{l}\text { No. of } \\
\text { the } \\
\text { tannery } \\
(\mathrm{N}=22)\end{array}$ & $\begin{array}{l}\text { No. of } \\
\text { workers } \\
\mathrm{N}=316\end{array}$ & $\begin{array}{l}\text { Suffering of } \\
\text { the workers } \\
\text { from health } \\
\text { problem } \\
(\%)\end{array}$ & $\begin{array}{l}\text { No. of } \\
\text { respond- } \\
\text { ents } \\
(n=200)\end{array}$ & OR & CI (95\%) & $\begin{array}{l}\mathrm{P}- \\
\text { value }\end{array}$ \\
\hline \multirow[t]{2}{*}{ Ventilation } & $\begin{array}{l}\text { well } \\
\text { ventilated }\end{array}$ & 2 & 23 & 8.5 & 17 & 1.70 & $0.65-4.45$ & 0.27 \\
\hline & $\begin{array}{l}\text { poor } \\
\text { ventilated }\end{array}$ & 20 & 293 & 91.5 & 183 & & & \\
\hline \multirow[t]{2}{*}{ Lighting } & $\begin{array}{l}\text { adequate } \\
\text { lighting }\end{array}$ & 3 & 29 & 11.0 & 22 & 1.92 & $0.79-4.65$ & 0.14 \\
\hline & poor lighting & 19 & 287 & 89.0 & 178 & & & \\
\hline \multirow[t]{2}{*}{ Temperature } & $\begin{array}{l}\text { comfortable } \\
\text { temperature }\end{array}$ & 1 & 5 & 1.5 & 3 & 0.87 & $0.14-5.27$ & 0.87 \\
\hline & $\begin{array}{l}\text { Not } \\
\text { comfortable } \\
\text { temperature }\end{array}$ & 21 & 311 & 98.5 & 197 & & & \\
\hline Chemical & no fume & 1 & 5 & 1.5 & 3 & 0.87 & $0.14-5.27$ & 0.87 \\
\hline Fume & with fume & 21 & 311 & 98.5 & 197 & & & \\
\hline $\begin{array}{l}\text { Noise } \\
\text { (mainly }\end{array}$ & $\begin{array}{l}\text { free from } \\
\text { noise }\end{array}$ & 0 & 0 & 0 & 0 & 0.58 & & 0.00 \\
\hline machinery) & Noisy & 22 & 316 & 100 & 200 & & & \\
\hline Smell & $\begin{array}{l}\text { normal } \\
\text { bad smell }\end{array}$ & $\begin{array}{c}0 \\
22\end{array}$ & $\begin{array}{c}0 \\
316\end{array}$ & $\begin{array}{c}0 \\
100\end{array}$ & $\begin{array}{c}0 \\
200\end{array}$ & 0.58 & & 0.00 \\
\hline $\begin{array}{l}\text { Effluents } \\
\text { and wastes } \\
\text { treatment } \\
\text { facility of } \\
\text { the tannery }\end{array}$ & $\begin{array}{l}\text { Yes } \\
\text { No }\end{array}$ & $\begin{array}{c}0 \\
22\end{array}$ & $\begin{array}{c}0 \\
316\end{array}$ & $\begin{array}{c}0 \\
100\end{array}$ & $\begin{array}{c}0 \\
200\end{array}$ & 0.58 & & 0.00 \\
\hline
\end{tabular}


Table 5 shows the association between disease and other risk factors. This study showed that females were more susceptible to disease (p-value 0.28). Seventy percent (p-value 0.28 ) respondents were suffering from diseases whose age ranged between 31 to 40 years. The result revealed an insignificant association between duration of job and disease ( $\mathrm{p}$ value 0.62 ). The study revealed that long time tannery working has a negative impact on heath, $75 \%$ respondents were suffering from diseases who worked above 16 years in the tannery ( $p$-value 0.62). An insignificant association (p-value 0.53 ) were also recorded between disease and personal protective equipment's use. Only 36.7\% workers used protective equipment's and they were using protective equipment's improperly which might cause health problem of the workers. For this reason, in this study an insignificant association between personal protective equipment's use and disease were found. It was noted that smokers were more likely to suffer from diseases (p-value 0.003).

Table 5. Association of health problems of the tannery workers with different risk factors

\begin{tabular}{|c|c|c|c|c|}
\hline \multicolumn{2}{|c|}{ Background characteristics } & $\begin{array}{l}\text { Health problems } \\
\text { percentage }\end{array}$ & $\begin{array}{l}\text { Number } \\
(\mathrm{N}=316)\end{array}$ & $\begin{array}{l}\mathrm{P}- \\
\text { value }\end{array}$ \\
\hline \multirow[t]{4}{*}{ Sex } & Male & 62.4 & 290 & 0.28 \\
\hline & Female & 73.1 & 26 & \\
\hline & $<20$ & 58.8 & 17 & 0.28 \\
\hline & $21-30$ & 58.5 & 147 & \\
\hline \multirow[t]{3}{*}{ Age } & $31-40$ & 70.2 & 104 & \\
\hline & $41+$ & 64.6 & 48 & \\
\hline & No education & 63.6 & 118 & 0.39 \\
\hline \multirow[t]{4}{*}{ Education } & Primary incomplete & 64.0 & 89 & \\
\hline & Primary complete & 66.0 & 53 & \\
\hline & Secondary incomplete & 65.1 & 43 & \\
\hline & Secondary complete & 45.5 & 13 & \\
\hline \multirow{4}{*}{$\begin{array}{l}\text { Income per month } \\
\text { (taka) }\end{array}$} & $<8000$ & 62.5 & 32 & 0.62 \\
\hline & $8001-10000$ & 60.6 & 170 & \\
\hline & $10001-12000$ & 69.0 & 87 & \\
\hline & $>12001$ & 63.0 & 27 & \\
\hline \multirow[t]{4}{*}{ Duration of job (year) } & $<5$ & 62.8 & 172 & 0.62 \\
\hline & $6-10$ & 63.6 & 99 & \\
\hline & $11-15$ & 56.0 & 25 & \\
\hline & $16-20$ & 75.0 & 20 & \\
\hline \multirow[t]{3}{*}{ Working hours (hour) } & $6-7$ & 62.5 & 8 & 0.99 \\
\hline & $8-9$ & 63.3 & 256 & \\
\hline & $10+$ & 63.5 & 52 & \\
\hline \multirow{4}{*}{$\begin{array}{l}\text { Protective equipment } \\
\text { use } \\
\text { Smoking status of the } \\
\text { tannery workers }\end{array}$} & Yes & 65.5 & 116 & 0.53 \\
\hline & No & 62.0 & 200 & \\
\hline & Yes (Smoke) & 70.8 & 171 & 0.003 \\
\hline & No (Do not smoke) & 54.5 & 145 & \\
\hline
\end{tabular}

The relation between health problems of the tannery workers and certain risk factors has been illustrated in Table 6. Most of the respondents $(53.5 \%)$ reported that they were not satisfied with their household income. A significant relation between household economic status and suffering from diseases were found in this study. Workers whose household 
status was deficient throughout the year were 1.86 time higher chance to suffer from diseases (CI: 1.15-3.00, p-value 0.01). Smokers were 0.50 time higher chance to suffer from diseases (CI: 0.31-0.78, p-value 0.003).

Table 6. Health problems of the tannery workers and certain risk factors, Hazaribagh, Bangladesh

\begin{tabular}{|c|c|c|c|c|c|}
\hline Factor & $\begin{array}{l}\text { Any one health proble } \\
\text { frequency }(n=200)\end{array}$ & $\begin{array}{l}\mathrm{em} \\
\% \\
\end{array}$ & OR & $95 \% \mathrm{CI}$ & P-value \\
\hline \multicolumn{6}{|c|}{ 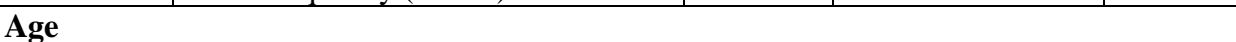 } \\
\hline$<35$ & 139 & 69.5 & 0.86 & $0.52-1.44$ & 0.58 \\
\hline$>35$ & 61 & 30.5 & & & \\
\hline \multicolumn{6}{|l|}{ Sex } \\
\hline Male & 181 & 90.5 & 0.61 & $0.24-1.50$ & 0.28 \\
\hline Female & 19 & 9.5 & & & \\
\hline \multicolumn{6}{|c|}{ Marital status } \\
\hline Married & 168 & 84 & 0.63 & $0.35-2.82$ & 0.11 \\
\hline Single & 32 & 16 & & & \\
\hline \multicolumn{6}{|l|}{ Education } \\
\hline Illiterate & 75 & 37.5 & 0.98 & $0.61-1.57$ & 0.93 \\
\hline literate & 125 & 62.5 & & & \\
\hline \multicolumn{6}{|c|}{ Household economic status（year) } \\
\hline Deficient & 107 & 53.5 & 1.86 & $1.15-3.00$ & 0.01 \\
\hline $\begin{array}{c}\text { Not } \\
\text { deficient }\end{array}$ & 93 & 46.5 & & & \\
\hline \multicolumn{6}{|c|}{ Duration of working in the tannery (year) } \\
\hline$<5$ & $108 \quad 5$ & 54.0 & 0.94 & $0.60-1.51$ & 0.84 \\
\hline$>5$ & 92 & 46.0 & & & \\
\hline \multicolumn{6}{|c|}{ Daily working hour } \\
\hline$<8$ & 133 & 66.5 & 0.71 & $0.44-1.14$ & 0.16 \\
\hline$>8$ & 67 & 33.5 & & & \\
\hline \multicolumn{6}{|c|}{ PPE use status of the workers } \\
\hline Yes & 76 & 38.0 & 0.82 & $0.53-1.38$ & 0.53 \\
\hline No & $124 \quad 6$ & 62.0 & & & \\
\hline \multicolumn{6}{|c|}{ Chemicals can cause health problems } \\
\hline Yes & $172 \quad 8$ & 86.0 & 0.70 & $0.37-1,28$ & 0.24 \\
\hline No & 28 & 14.0 & & & \\
\hline \multicolumn{6}{|c|}{ Smoking status } \\
\hline Yes & 121 & 60.5 & 0.50 & $0.31-0.78$ & 0.003 \\
\hline No & 79 & 39.5 & & & \\
\hline
\end{tabular}

This poor economic status affects their health seeking behaviors as well as maintaining their health; moreover, they did not get any medical support from the tannery owners. Among 200 workers with diseases 161 workers received medical treatment and they attended different health care services centers for treatment at a time. The data also showed that $23.1 \%$ respondents seek advice from self-care/family/relative/neighbor/friend, $26.9 \%$ from qualified allopathic doctors, $4.7 \%$ from para-professional, $11.1 \%$ from 
unqualified allopathic (local drug store/ pharmacy). All the respondents reported that no tannery industry providedmedical treatment to the sick workers and there were no healthcare facilities or healthcare personnel of the tannery. (Table 7)

Table 7. Health seeking behavior of the tannery workers, Hazaribagh, Bangladesh

\begin{tabular}{l|c|c}
\hline $\begin{array}{l}\text { Seeking advice or treatment status of the tannery } \\
\text { workers }\end{array}$ & $\begin{array}{c}\text { Number of } \\
\text { workers }(\mathrm{N}=316)\end{array}$ & Percentage \\
\hline Receive treatment & 161 & 50.9 \\
$\begin{array}{l}\text { Do not receive treatment } \\
\text { Medical treatment suppliment to the sick workers by the management**** }\end{array}$ & 49.1 \\
$\quad$ Yes & 0 & 0.0 \\
No & 307 & 97.2 \\
Availability of health care facility of the & & \\
tannery**** & 0 & 0.0 \\
Yes & 307 & 97.2 \\
No & & 23.1 \\
Health care Provider for the tannery workers & 73 & 4.7 \\
Self-care/Family/relative/Neighbor/friend & 15 & 26.9 \\
Para-professional & 85 & 11.1 \\
Qualified allopathic(MBBS), & 35 & 1.6 \\
Unqualified allopathic(local drug store/ & & 1.3 \\
pharmacy) & 5 & \\
Homeopathy/ Ayurvedic / Kabiraj & 4 & \\
Traditional healers (Imam/Ojhaetc & & \\
\hline *** There were 9 case missing & &
\end{tabular}

*** There were 9 case missing

**** There were 9 case missing

According to the findings of this study, working environment, types of work, way of work, smoking, use of PPE and lifestyle has a great impact on the health of the tannery workers. Smoking and household income of the respondents were found significantly associated with the morbidity of the tannery workers. Strict enforcements of Bangladesh's Labour Act (2006) along with more concern on OHAS issue are strongly recommended for both government and tannery employers as soon as possible. Exclusive hospital, proper training focusing on PPE use and chemicals along with safe housing for tannery workers would be beneficial to the tannery workers. For bright future of tannery industries the government of Bangladesh should take adequate preventive measures in tannery industrial activities to ensure safe, sound and healthy environment.

\section{REFERENCES}

Arjunan, C. 2015. A Study on Tannery Worker's Health Problems in Erode District. International Conference on Innovations in Research in the Field Of Social Science (ICIRFSS).IOSRJHSS. 01-05.

Azom, M.R., Mahmud, K., Yahya, S. M., Sontu, A. and Himon, S.B. 2012. Environmental Impact Assessment of Tanneries: A Case Study of Hazaribag in Bangladesh. IJESD. 3(2): 152156. 
Chowdhury, A. D. 2011. Tannery Bisha Akranto Trish Hazar Manus. Bangladesh Protidin. p-4, c$5,2011$.

Febriana, S.A., Jungbauer, F., Soebono, H. and Coenraads, P. J. 2012. Inventory of the chemicals and the exposure of the workers' skin to these at two leather factories in Indonesia. Int. Arch. Occup. Environ.Health. 85 (5):517-526 DOI 10.1007/s00420-011-0700-1.

Gangopadhyay, S., Ara, T., Dev, S., Ghoshal, G. and Das, T. 2011.An Occupational Health Study of the Footwear Manufacturing Workers of Kolkata, India. Ethno. Med. 5(1): 11-15.

GTZ. 2000. Leather Sector VC Assessment GTZ Progress, 3-4.Retrieved on September, 18, 2013 from http://www.scribd.com/doc/28847920/Leather-Sector-VCAssessment-GTZProgress.

Human Rights Watch. 2012. Toxic Tanneries: The Health Repercussions of Bangladesh's Hazaribagh Leather. P. 6-14 and 20-55.

Huq, S. M. I. 1998. Critical Environmental Issues Relating to tanning Industries in Bangladesh. In: Naidu, R., Willett, I. R., Mahimarajah, S., Kookana, R. and Ramasamy, K. (eds.), 2000. Towards Better Management of Soils Contaminated with Tannery waste, Proceedings of a workshop held at the Tamil Nadu Agricultural University, Coimbatore,

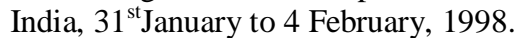
www.aciar.gov.au/files/node/319/PRO088\%20part\%201.pdf. Retrieved on 5th June 2005.

Larson., W.E., Gillery, J.R. and Linden, D.R. 1975. Consequences of waste disposal on land.Soil Water Censerv. 2: 68.

Nuruzzaman, M., Ullah, S.M., Islam, A., Rahman, S. and Rashid, H .1992. Effects of industrial waste on soil properties and crop growth. Regional workshop on "Environmental impacts from fertilizers, Agrochemicals and industrial wastes. Under the project Chemcial Research and Environmental Needs (REN)”. P. 15-25.

Rastogi, S. K., Pandey, A. and Tripathi, S.2008. Occupational health risks among the workers employed in leather tanneries at Kanpur. Indian J Occup. Environ. Med. 12(3): 132-135. doi: 10.4103/0019-5278.44695

Were, F.H., Moturi, C.M., Kamau, G.N. and Wafula, G.A. 2013.Respiratory diseases due to occupational exposure to nickel and chromium among factory workers in Kenya. $J$ Community Med. Health Educ. 3(7): 1-7.

Yogaraj, G. A., Devi, R.U. and Kumar, J.K. 2014. A cross-sectional study on Morbidity Pattern among Leather Factory workers at Sripuram, Chennai, Tamil Nadu. India. Research Journal of Pharmaceutical, Biological and Chemical Sciences. 5(5): P 1346. 